Crop Breeding and Applied Biotechnology 15: 169-174, 2015

Brazilian Society of Plant Breeding. Printed in Brazil

\title{
ARTICLE
}

http://dx.doi.org/10.1590/1984-70332015v15n3a29

\section{Implications of early selection for resistance to anthracnose in genetic breeding of common bean}

\author{
José Maria Villela Pádua ${ }^{1 *}$, Magno Antonio Patto Ramalho ${ }^{1}$ and Ângela de Fátima Barbosa Abreu²
}

Received 03 June 2013

Accepted 13 October 2014

\begin{abstract}
It is questionable if early selection for resistance to Colletotrichum lindemuthianum reduces the efficiency of selection for grain yield in common beans. For this, it was used the segregating population of the cross between two common bean lines: CI107 (susceptible) x BRSMG Madrepérola (resistant). Selection for resistance was carried out in $F_{2}$ and $F_{3}$, obtaining three types of progenies: not selected $(A)$, selected only in $F_{2}(B)$, and selected in $F_{2}$ and $F_{3}(C)$. The progenies obtained were evaluated for grain yield and pathogen occurrence in experiments. In $F_{3: 5}$, it was used 289 treatments (96 progenies A, 96 B, 95 C and 2 checks (T)); in $F_{3: 6,} 196$ treatments (64 A, 64 B, $64 \mathrm{C}$ and $4 \mathrm{~T})$; in $F_{3: 7} 81$ treatments $(26 \mathrm{~A}, 26 \mathrm{~B}, 26 \mathrm{C}$ and $3 \mathrm{~T})$. Selection of plants resistant to anthracnose in early generations increases the successful selection for grain yield in later generations.
\end{abstract}

Key words: Plant breeding, Phaseolus vulgaris, Colletotrichum lindemuthianum.

\section{INTRODUCTION}

There are several factors that contribute to yield reduction of common bean (Phaseolus vulgaris L.), among which are the occurrence of virus, bacteria, fungi and certain types of pests (Miklas et al. 2006, Singh and Schwartz 2010, Carvalho et al. 2013, Pereira et al. 2013a). It should be noted that the main biotic stress which affects grain yield of common bean in Brazil is the occurrence of diseases caused by fungi. Among them, anthracnose, which is caused by Colletotrichum lindemuthianum, stands out. It is found in many regions of Brazil and in all crop seasons (GonçalvesVidigal et al. 2012).

Colletotrichum lindemuthianum resistance is widely studied all over the world. "Since the first anthracnose resistance gene was described early in the twentieth century, twenty resistance genes (named as $\mathrm{Co}$-) that give resistance to specific anthracnose isolates or races pathogenic in common bean have been described" (Ferreira et al. 2014). All of these genes are independent, and in 19 of them, the resistance is conferred by the dominant allele and only in 1 , it is conferred by the recessive allele.

In common bean genetic breeding, different traits are involved, among which are grain yield, plant architecture, grain type, and resistance to pathogens (Pereira et al. 2013b). Some of these traits have low heritability $\left(\mathrm{h}^{2}\right)$, such as grain yield (Bernardo 2010). In this case, selection is only effective after some generations of endogamy, and evaluation by means of well-conducted experiments. However, early selection in $\mathrm{F}_{2}$ or $\mathrm{F}_{3}$ generations should be efficient when other traits are considered, such as resistance to anthracnose, which normally shows high heritability, especially when selection is carried out in a greenhouse.

There are some reports in the literature regarding the effect of early selection for a high heritability trait in selection for grain yield in advanced generations (Santos et al. 2001, Padi and Ehlers 2008). However, no report was found regarding the effect of early selection with a view toward pathogen resistance in common bean.

In light of the above, the aim of this study was to evaluate the effect of selection in $\mathrm{F}_{2}$ or in $\mathrm{F}_{2}$ and $\mathrm{F}_{3}$ generations for resistance to Colletotrichum in genetic variability for grain yield, and the success obtained through selection in more advanced generations.

\footnotetext{
${ }^{1}$ Universidade Federal de Lavras (UFLA), Departamento de Biologia, C.P. 3037, 37.200-000, Lavras, MG, Brazil. *E-mail: josemaria@agronomia.ufla.br

${ }^{2}$ Embrapa Arroz e Feijão, Rodovia GO-462, km 12, C.P. 179, 75.375-000, Santo Antônio de Goiás, GO
} 


\section{MATERIAL AND METHODS}

The experiments were carried out in an experimental area of the Universidade Federal de Lavras (lat $21^{\circ} 14^{\prime} \mathrm{S}$, long $40^{\circ} 17^{\prime} \mathrm{W}$, alt $918 \mathrm{~m}$ asl - UFLA), Lavras, MG, Brazil.

The segregating population was obtained from the cross between the lines CI-107 and BRSMG-Madrepérola. CI-107 line belongs to the UFLA breeding program, it has good grain yield, and is a carioca type bean (beige with brown stripes), with good appearance and quick cooking. The main disadvantage is its susceptibility to various races of $C$. lindemuthianum (Silva et al. 2011). BRSMG Madrepérola cultivar presented good grain yield, it is a carioca type bean, and it is light colored and presents late darkening. In addition, it is resistant to anthracnose races $55,65,73,81$, 89, 95 and 453 (Carneiro et al. 2012).

The crosses were carried out in a greenhouse in the first semester of 2010. $\mathrm{F}_{2}$ population seeds were divided into two samples, A and B. No selection was carried out in sample A. However, in sample B, selection was carried out in greenhouse for resistance to anthracnose (Figure 1).

Inoculation was carried out in greenhouse using the isolate LV- 180 of race 65 . The inoculation methodology was similar to that adopted by Silva et al. (2011). Seeds were sown in 128-cell trays with substrate. After germinating, seedlings were inoculated after complete expansion of the primary leaves, spraying both surfaces of the leaves and the stem using the "De Vilbiss" sprayer, activated by a compressor over the entire seedling up to the point of runoff. After inoculation, trays were incubated in a humidity chamber for 48 hours with a temperature of approximately $21^{\circ} \mathrm{C}$, and 12-hour photoperiod.

After that, the trays were transferred to a greenhouse, where they remained until symptoms evaluation, according to the modified scoring scale of Schoonhoven and PastorCorrales (1987), which was carried out at seven days after inoculation. Then, resistant individuals were transplanted in the field. $\mathrm{F}_{3}$ (resistant) generation seeds were obtained at harvest.

Seeds of the population derived from resistant plants of the previous step were once more divided into two samples: the first, sample B, whose evaluation of resistance to $C$. lindemuthianum occurred only in $\mathrm{F}_{2}$, and the second, sample $\mathrm{C}$, whose selection for resistance to anthracnose was once more carried out in $\mathrm{F}_{3}$ generation, in a similar way to that described above.

In February 2011, samples A and B were sown in bulk. As for sample $C$, which underwent selection in $F_{3}$ gen- eration after having been inoculated in a greenhouse, its resistant plants were transplanted in the field. Plants from each population were collected individually, giving rise to the progenies of $\mathrm{F}_{3: 4}$ generation.

In July 2011, all $\mathrm{F}_{3: 4}$ progenies were sown in the field for seed multiplication, and $\mathrm{F}_{3: 5}$ progenies (Figure 1) were obtained. These progenies obtained from each population (96 progenies from the $\mathrm{A}$ and $\mathrm{B}$ samples, and 95 progenies from the $\mathrm{C}$ sample), and the parents, were evaluated using a 17x17 triple lattice design, with plots of two two-meter rows, spaced $0.6 \mathrm{~m}$. This experiment was sown in November 2011. Data regarding grain yield were collected.

For composing $\mathrm{F}_{3: 6}$ generation, the 64 progenies with the greatest grain yield were selected from each one of the samples. These progenies were evaluated in February 2012. A 14x14 triple lattice design was used, composed of 192 progenies and four controls (the parents, BRSMG Majestoso and BRSMG Talismã), with plots identical to those of $\mathrm{F}_{3: 5}$ generation. In this generation, data regarding anthracnose severity and grain yield were collected. In the case of pathogen occurrence, a diagrammatic scale was used, in which score 5 was attributed to absence of symptoms, and score 1 was attributed to the plant nearly totally overtaken by the disease.

After analyses of the data from $\mathrm{F}_{3: 6}$ generation, 26 progenies with the greatest grain yield were selected from each one of the samples, giving rise to $\mathrm{F}_{3: 7}$ generation. In this experiment, a 9x9 triple lattice design was used, composed of 78 progenies and three controls (the parents and another cultivar), with plots equal to those of the other generations. This experiment was sown in July 2012. All the other procedures were similar to those of the previous evaluations.

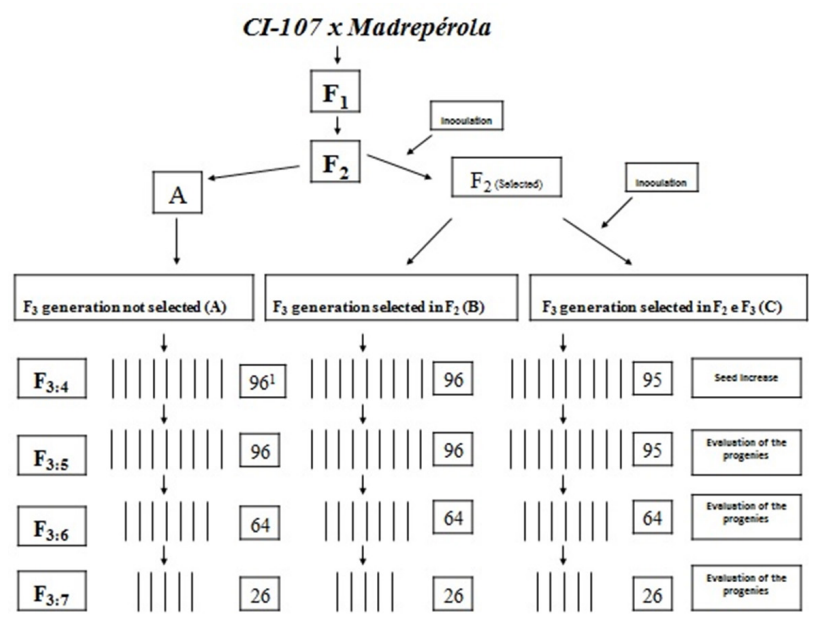

Figure 1. Schema of the experimental procedure used. ${ }^{1}$ Number of progenies evaluated from each origin. 
Data were subjected to analysis of variance (ANOVA) in each generation, and subsequently joint analysis was carried out. Means of anthracnose severity score obtained in samples A, B and C were submitted to Scott and Knott (1974) test. These analyses were carried out using the R software (R Development Core Team 2014). Based on the mathematical expectations of the mean squares of the analyses of variance, estimates of the genetic and phenotypic parameters were obtained, using a procedure similar to that presented by Ramalho et al. (2012) and Bernardo (2010). The confidence interval of heritability $\left(\mathrm{h}^{2}\right)$ was also obtained, estimated by the expressions of Knapp et al. (1985). The estimates were obtained per generation (data not presented) and in each the joint analysis.

Gain expected from selection in each group of progenies (selected in $\mathrm{F}_{2}, \mathrm{~F}_{2}$ and $\mathrm{F}_{3}$, and non-selected) was estimated by the expression: $G S=i \frac{\operatorname{Cov}_{g g}}{\sqrt{\sigma_{f}^{2}}}$, with selection intensity of (i) $=20 \%$, in which $\operatorname{Cov}_{g g^{\prime}}$ is the covariance on a progeny mean basis in the $\mathrm{g}^{\text {th }}$ and $\mathrm{g}^{\text {th }}$ generation, while $\sigma_{\mathrm{F}}^{2}$ is the phenotypic variance on a progeny mean basis in the generations $\mathrm{g}^{\text {th }}$. The error associated with gain from selection (GS) was also estimated, using the expression presented by Bridges et al. (1991).

\section{RESULTS AND DISCUSSION}

Colletotrichum lindemuthianum, the agent which causes anthracnose in common bean, is a pathogen of innumerable races (Miklas et al. 2006, Singh and Schwartz 2010). Some of them are found in the southern region of the state of Minas Gerais, predominantly race 65 (Davide et al. 2009, Ishikawa et al. 2011). For this reason, this race was chosen for $\mathrm{F}_{2}$ generation inoculation. Available information indicates that the CI107 parent is susceptible to most of the races of this pathogen (Silva et al. 2011), whereas BRSMG Madrepérola is resistant to some races, among them, race 65 (Carneiro et al. 2012).

In the result of joint analysis of variance for the anthracnose severity score, a significant difference was detected among treatments $(\mathrm{P} \leq 0.01)$ (Table 1$)$. Sources of variation among controls, among origins and among progenies in each origin were also significant $(\mathrm{P} \leq 0.05)$. Interactions involving treatments $\mathrm{x}$ generations were significant in all cases, except for the contrast between controls $\mathrm{x}$ generations, and between origin $\mathrm{x}$ generations. Progenies derived from selection carried out in $\mathrm{F}_{2}$ generation were those that on average showed the least symptoms (greatest mean value) (Table 2). It may be observed that the mean value of progenies was less than that of controls in $\mathrm{F}_{3: 6}$ generation.
Table 1. Summary of joint analysis of variance of anthracnose severity score and of grain yield $\left(\mathrm{g} \mathrm{plot}^{-1}\right)$ of common bean, obtained in evaluation of progenies selected in $\mathrm{F}_{2}$, in $\mathrm{F}_{2}$ and $\mathrm{F}_{3}$, and non-selected progenies

\begin{tabular}{|c|c|c|c|c|}
\hline \multirow{2}{*}{ Sourcer of variation } & \multicolumn{2}{|c|}{ Disease severity $^{\mathrm{a}}$} & \multicolumn{2}{|c|}{ Grain yield $^{\mathrm{b}}$} \\
\hline & df & MS & df & MS \\
\hline Generations (G) & 1 & $52.87 * *$ & 2 & $12493370.11 * *$ \\
\hline Treat (Adjusted) & 79 & $1.36^{* *}$ & 79 & $43887.96^{* *}$ \\
\hline Controls & 1 & $1.69 * *$ & 1 & 329.99 \\
\hline Control vs Prog. & 1 & 0.20 & 1 & $69751.81 * *$ \\
\hline Among Origins & 2 & $11.52 * *$ & 2 & $453535.54 * *$ \\
\hline Among $\mathrm{A}^{1}$ & 25 & $1.04 * *$ & 25 & 14256.70 \\
\hline Among B ${ }^{2}$ & 25 & $1.14 * *$ & 25 & 50429.90 \\
\hline Among $\mathrm{C}^{3}$ & 25 & $1.10^{*}$ & 25 & $34913.24 * *$ \\
\hline Treat x Generations (G) & 79 & $0.42 * *$ & 158 & $21840.57 * *$ \\
\hline Betw. Cont. X G & 1 & 0.01 & 2 & 10556.32 \\
\hline Cont. vs Prog X G & 1 & $2.84 * *$ & 2 & $247416.36^{* *}$ \\
\hline Betw. Origins X G & 2 & 0.05 & 4 & 4583.00 \\
\hline Between A X G & 25 & $0.38 * *$ & 50 & 13700.86 \\
\hline Between B X G & 25 & $0.27 * *$ & 50 & $33185.22 * *$ \\
\hline Between C x G & 25 & $0.56^{* *}$ & 50 & 11444.58 \\
\hline Mean Error & 487 & 0.07 & 1015 & 10555.12 \\
\hline $\mathrm{r}_{\mathrm{gq}}(\%)^{+}$ & & 83.00 & & 70.88 \\
\hline
\end{tabular}

${ }^{a}$ Generations $F_{3: 6}$ and $F_{3: 7}$ were considered ${ }^{b}$ Generations $F_{3: 5}, F_{3: 6}$ and $F_{3: 7}$ were considered. $* * * * ; 6$ test significant at $5 \%$ and $1 \%$ probability, respectively. $1,2,3$ Progenies non-selected, progenies selected in $\mathrm{F}_{2}$, and progenies selected in $\mathrm{F}_{2}$ and $\mathrm{F}_{3}$, respectively. ${ }^{+}$Selective accuracy.

The existence of variation for the disease severity score trait among progenies may also be confirmed by means of heritability estimates. Comparing the heritability estimates for selection among progenies, according to origin in joint analysis, it is observed that they were similar (Table 3). $\mathrm{F}_{3: 6}$ generation highlights what has already been mentioned: there is wide variation among progenies, regardless of origin. This result, in principle, shows that even though selection had been made for resistance to anthracnose in $\mathrm{F}_{2}$ or $\mathrm{F}_{2}$ and $\mathrm{F}_{3}$ generations, heritability estimates were similar to that obtained in the progenies derived from the population without selection for anthracnose. Although early selection is efficient in $\mathrm{F}_{2}$ or in $\mathrm{F}_{2}$ and $\mathrm{F}_{3}$ for the pathogen, this selection did not completely eliminate the individuals that have the recessive allele. It should also be carried out in

Table 2. Estimates of anthracnose severity score of common bean. Obtained in evaluation of $\mathrm{F}_{3.6}$ and $\mathrm{F}_{3.7}$ progenies derived from non-selected progenies (A), progenies selected in $F_{2}(B)$ and progenies selected in $F_{2}$ and $\mathrm{F}_{3}(\mathrm{C})$

\begin{tabular}{lccccc}
\hline \multirow{2}{*}{ Generation } & \multicolumn{3}{c}{$\begin{array}{c}\text { Selection for } \\
\text { Colletotrichum }\end{array}$} & \multirow{2}{*}{$\begin{array}{c}\text { Mean value } \\
\text { of progenies }\end{array}$} & Controls \\
\cline { 2 - 4 } & $\mathrm{A}$ & $\mathrm{B}$ & $\mathrm{C}$ & & \\
\hline $\mathrm{F}_{3: 6}$ & $3.2 \mathrm{c} *$ & $3.8 \mathrm{a}$ & $3.3 \mathrm{~b}$ & 3.4 & 4.2 \\
$\mathrm{~F}_{3: 7}$ & $4.1 \mathrm{c}$ & $4.6 \mathrm{a}$ & $4.4 \mathrm{~b}$ & 4.4 & 4.5 \\
Jointly & $3.4 \mathrm{c}$ & $4.0 \mathrm{a}$ & $3.5 \mathrm{~b}$ & 3.6 & 3.6 \\
\hline
\end{tabular}

* Severity score of $C$. lindemuthianum, in which 5 indicates absence of symptoms and 1 plant death. Mean values followed by the same letters in the lines belong to the same group at the 5\% level of significance by the Scott and Knott (1974) test 
future generations.

In joint analysis of variance for grain yield, a significant difference $(\mathrm{P} \leq 0.01)$ was detected among treatments (Table 1). In decomposition of the treatment source of variation, there were significant differences $(\mathrm{P} \leq 0.01)$ among origins, among progenies selected in generation $\mathrm{F}_{2}$ and $\mathrm{F}_{3}$ and in the control vs. progeny contrast. Progeny $\mathrm{x}$ generation interaction was significant $(\mathrm{P} \leq 0.01)$. Interactions involving controls vs. progenies $\mathrm{x}$ generations, and between progenies selected in $\mathrm{F}_{2} \mathrm{x}$ generations were also significant. The greatest mean yields were obtained from progenies selected at an early stage for resistance to C. lindemuthianum (Table 4). The result of the 25 progenies common to the three generations showed that the mean value of the progenies whose plants were selected in $\mathrm{F}_{2}$ was $17 \%$ greater than the mean value of the progenies which were not selected for resistance to anthracnose.

In this study, what is really of interest is verifying if early selection for resistance to anthracnose may affect future success in selection for grain yield. The response to this question may be given considering some different perspectives. The first of them would be the heritability estimates for grain yield for selection among progenies. Heritability estimates for grain yield also show the existence of variation among progenies for all the origins. In principle, for grain yield, heritability estimates may be considered as similar for the different origins since there was overlapping in the confidence interval (Table 3). Considering all progenies, heritability estimate was of great magnitude. This value is comparable to most of heritability estimates for grain yield with a view toward selection on a progeny mean basis available in the literature (Ramalho et al. 2012). In principle, this result indicates that environmental variation in relation to genetic variation among progenies was small and that

Table 3. Estimates of genetic variance among progenies $\left(\sigma_{\mathrm{p}}^{2}\right)$ and phenotypic variance among mean values of progenies $\left(\sigma_{\mathrm{F}}^{2}\right)$, heritability $\left(\mathrm{h}^{2}\right)$ for selection in the mean value of progenies and lower (LI) and upper (LS) limits of $h^{2}$ considering joint analyses, obtained in evaluation of non-selected progenies (A), progenies selected in $\mathrm{F}_{2}(\mathrm{~B})$ and progenies selected in $\mathrm{F}_{2}$ and $\mathrm{F}_{3}(\mathrm{C})$

\begin{tabular}{lccccc}
\hline Trait & $\begin{array}{c}\text { Components } \\
\text { of variance }\end{array}$ & $\mathbf{A}$ & $\mathbf{B}$ & $\mathbf{C}$ & $\begin{array}{c}\text { All the } \\
\text { progenies }\end{array}$ \\
\hline \multirow{3}{*}{ Disease } & $\sigma_{\mathrm{P}}^{2}$ & 0.22 & 0.29 & 0.18 & 0.31 \\
severity $^{\mathrm{a}}$ & $\sigma_{\mathrm{F}}^{2}$ & 0.35 & 0.38 & 0.37 & 0.45 \\
& $\mathrm{~h}^{2}(\%)$ & 63 & 76 & 49 & 69 \\
& $(\mathrm{LI} / \mathrm{LS})$ & $(19 / 84)$ & $(47 / 89)$ & $(-14 / 77)$ & $(52 / 80)$ \\
\hline \multirow{4}{*}{ Grain } & $\sigma_{\mathrm{P}}^{2}$ & 185.28 & 5748.23 & 7822.89 & 7349.13 \\
yield $^{\mathrm{b}}$ & $\sigma_{\mathrm{F}}^{2}$ & 1584.08 & 5603.22 & 3879.25 & 4876.44 \\
& $\mathrm{~h}^{2}(\%)$ & 4 & 34 & 67 & 50 \\
& $(\mathrm{LI} / \mathrm{LS})$ & $(-99 / 50)$ & $(-37 / 66)$ & $(32 / 82)$ & $(26 / 66)$ \\
\hline
\end{tabular}

${ }^{a}$ Generations $F_{3: 6}$ and $F_{3: 7}$ were considered ${ }^{b}$ Generations $F_{3: 5}, F_{3: 6}$ and $F_{3: 7}$ were considered. there is expressive genetic variation among progenies. This condition is fundamental for what is intended from this study. When the heritability estimates are compared according to the origin of progenies, they are similar; in other words, there is overlapping in the confidence intervals. It may thus be concluded that early selection for resistance to anthracnose did not affect the variability for grain yield in later generations.

Another perspective for evaluating the effect of early selection is by means of the proportion of progenies that would be selected according to their origin (Table 4). Among the $20 \%$ of progenies with the greatest grain yield, $68.75 \%$ came from early selection. It may be concluded that selection for grain yield was not affected by the early selection made in $\mathrm{F}_{2}$ generation for resistance to anthracnose. On the contrary, it was even beneficial. That occurs since the occurrence of anthracnose negatively affects grain yield; in this study the variation in disease severity explained more than $60 \%$ of the variation in grain yield, considering all progenies (data not shown). Therefore, the most susceptible plants are the least productive ones (Abreu et al. 2003).

A final perspective for evaluating the effect of early selection carried out in $\mathrm{F}_{2}$ or in $\mathrm{F}_{2}$ and $\mathrm{F}_{3}$ on grain yield in advanced generations is the estimate of progress expected from selection for the first trait. The estimate of gain from selection (GS) considering the $20 \%$ of the highest yielding progenies, regardless of the origin of progenies, was $18.6 \%$ in the overall mean value, which is high. This value is comparable to the estimates reported in the literature (Ramalho et al. 2012), highlighting the existence of great genetic variability among progenies, and the good experimental precision in evaluation. The estimate of gain from selection according to origin was different. Gain from selection was greater for progenies selected at an early stage in $\mathrm{F}_{2}$ and in $\mathrm{F}_{2}$ and $\mathrm{F}_{3}$ (Table 4). It may be concluded that early selection does not affect variability for grain yield, and it

Table 4. Estimates of gains expected from selection (GS) for grain yield $\left(\mathrm{g} \mathrm{plot}^{-1}\right)$ of common bean,obtained in evaluation of $\mathrm{F}_{3: 5}, \mathrm{~F}_{3: 6}$ and $\mathrm{F}_{3: 7}$ progenies, and percentage of progenies in the joint analyses among the $20 \%$ best progenies for grain yield $\left(\mathrm{g} \mathrm{plot}^{-1}\right)$ of common bean derived from non-selected progenies $(\mathrm{A})$, progenies selected in $\mathrm{F}_{2}(\mathrm{~B})$ and progenies selected in $\mathrm{F}_{2}$ and $\mathrm{F}_{3}(\mathrm{C})$

\begin{tabular}{lcccc}
\hline Parameters & A & B & C & $\begin{array}{c}\text { All } \\
\text { progenies }\end{array}$ \\
\hline Mean value & 504.76 & 591.87 & 573.2 & 528.85 \\
Mean of 20\% & 564.55 & 689.19 & 634.1 & 658.54 \\
GS & $15.5(23.9)^{1}$ & $76.9(31.11)$ & $67.8(27.9)$ & $98.6(22.3)$ \\
GS (\%) & 3.1 & 12.9 & 11.8 & 18.6 \\
\hline Classification (20\%) & $6.25 \%$ & $68.75 \%$ & $25.00 \%$ & \\
\hline
\end{tabular}

${ }^{1}$ Error associated with estimate of gain from selection. 
contributed to expand the success expected from selection for grain yield in more advanced generations. Moreover, it avoids the loss of time dedicated to progenies susceptible to the pathogen, which would probably be those of lower grain yield.

Similar results of early selection on traits of greater heritability and their effect on selection for grain yield in more advanced generations are found in the literature, such as in common bean (Santos et al. 2001) and in cowpea (Padi and Ehlers 2008). In the case of the study of Santos et al. (2001), early selection was carried out for grain type, a trait which, at least in principle, does not undergo the action of natural selection, and is not correlated with grain yield, in contrast to resistance to anthracnose reported in this study. Thus, it was evident that when the trait of greater heritability positively affects grain yield, early selection for this trait is even more advantageous.

\section{CONCLUSIONS}

Early selection carried out in $\mathrm{F}_{2}$ and $\mathrm{F}_{3}$ for resistance to anthracnose in common bean does not reduce the variability for grain yield in more advanced generations.

A large part of the variation in grain yield is due to the variation in the anthracnose severity score. Thus, the selection of plants resistant to anthracnose in $\mathrm{F}_{2}$ or in $\mathrm{F}_{2}$ and $\mathrm{F}_{3}$ increases success in selection for grain yield in more advanced generations.

\section{ACKNOWLEDGMENTS}

The authors thank the National Council of Scientific and Technological Development (CNPq) for financial support.

\section{Implicações da seleção precoce para resistência à antracnose no melhoramento genético do feijoeiro comum}

Resumo - É questionável se a seleção precoce para resistência ao Colletotrichum lindemuthianum reduz a eficiência da seleção para produtividade de grãos no feijoeiro comum. Para responder esta questão foi utilizada a população segregante do cruzamento entre duas linhagens de feijão: CI107 (suscetivel) x BRSMG Madrepérola (resistente). A seleção para resistência foi realizada em $F_{2}$ e $F_{3}$, obtendo-se três tipos de progênies: não selecionadas $(A)$, selecionadas somente em $F_{2}(B)$, e selecionadas em $F_{2}$ e $F_{3}(C)$. As progênies obtidas foram avaliadas para produtividade de grãos e ocorrência do patógeno em experimentos. Na $F_{3: 5}$ foram utilizados 289 tratamentos (96 progênies A, 96 B, 95 C e 2 testemunhas (T)); na $F_{3: 6,} 196$ tratamentos (64 A, 64 B, 64 C e 4 T); na F $F_{3: 7,} 81$ tratamentos (26 A, 26 B, $26 \mathrm{C}$ e $3 \mathrm{~T}$ ). A seleção de plantas resistentes à antracnose em gerações precoces aumenta o sucesso com a seleção para produtividade de grãos em gerações avançadas.

Palavras-chave: Melhoramento de plantas, Phaseolus vulgaris, Colletotrichum lindemuthianum.

\section{REFERENCES}

Abreu AFB, Ramalho MAP, Gonçalves FMA and Mendonça HA (2003) Utilização da produtividade de grãos na seleção para resistência ao Colletotrichum lindemuthianum no feijoeiro. Ciência e Agrotecnologia 27: 363-369.

Bernardo R (2010) Breeding for quantitative traits in plants. Stemma, Woodbury, 400p.

Bridges WC, Knapp SP and Cornelius PL (1991) Standard errors and confidence interval estimators for expected selection response. Crop Science 31: 253-255.

Carneiro JES, Abreu AFB, Ramalho MAP, Paula Jr TJP, Peloso MJ, Melo LC, Pereira HS, Pereira Filho IA, Martins M, Vieira RF, Carneiro PCS, Santos JB, Faria LC, Costa JGC and Teixeira H (2012) BRSMG Madrepérola: common bean cultivar with late-darkening Carioca grain. Crop Breeding and Applied Biotechnology 12: 281-284.

Carvalho RSB, Lima IA, Alves FC and Santos JB (2013) Selection of carioca common bean progenies resistant to white mold. Crop Breeding and Applied Biotechnology 13: 172-177.

Davide LMC and Souza EA (2009) Pathogenic variability within race 65 of Colletotrichum lindemuthianum and its implications for common bean breeding. Crop Breeding and Applied Biotechnology 9: 23-30.

Ferreira JJ, Campa A and Kelly JD (2014) Organization of genes conferring resistance to anthracnose in common bean. In Varshney RK and Tuberosa R (Eds) Translational genomics for crop breeding: biotic stress. Vol. 1, John Wiley \& Sons, Chichester, p.151-175.

Gonçalves-Vidigal MC, Meirelles AC, Poletine JP, Sousa LL, Cruz AS, Nunes MP, Lacanallo GF and Vidigal Filho PS (2012) Genetic analysis of anthracnose resistance in Pitanga dry bean cultivar. Plant Breeding 131: 423-429.

Ishikawa FH, Ramalho MAP and Souza EA (2011) Common bean lines as potential differential cultivars for race 65 of Colletotrichum lindemuthianum. Journal of Plant Pathology 93: 461-464.

Knapp SJ, Stroup WW and Ross WM (1985) Exact confidence intervals for heritability on a progeny mean basis. Crop Science 25: 192-194.

Miklas PN, Kelly JD, Beebe SE and Blair MW (2006) Common bean breeding for resistance against biotic and abiotic stresses: From classical to MAS breeding. Euphytica 147: 105-131.

Padi FK and Ehlers JD (2008) Effectiveness of early generation selection in cowpea for grain yield and agronomic characteristics in Semiarid 
JMV Pádua et al.

West Africa. Crop Science 48: 533-540.

Pereira AC, Poersch NL, Carneiro PCS, Paula Júnior TJ, Barros EG and Carneiro JES (2013a) Introgression of resistance to pathogens in common bean lines with the aid of molecular markers. Crop Breeding and Applied Biotechnology 13: 120-126.

Pereira HS, Melo LC, Faria LC, Wendland A, Del Peloso MJ, Costa JGC, Nascente AS, Díaz JLC, Carvalho HWL, Almeida VM, Melo CLP, Costa AF, Posse SCP, Magaldi MCS, Abreu AFB, Guimarães CM, Oliveira JP, Moreira JAA, Martins M and Souza Filho BF (2013b) BRS Esteio - Common bean cultivar with black grain, high yield potential and moderate resistance to anthracnose. Crop Breeding and Applied Biotechnology 13: 273-276.

R Development Core Team (2014) R: A language and environment for statistical computing. R Foundation for Statistical Computing. Available at $<$ http://www.R-project.org $>$. Acessed in May, 2013.

Ramalho MAP, Abreu AFB, Santos JB and Nunes JAR (2012) Aplicações da genética quantitativa no melhoramento de plantas autógamas. Editora UFLA, Lavras, 522p.

Santos VS, Ramalho MAP, Carneiro JES and Abreu AFB (2001) Consequences of early selection for grain type in common bean breeding. Crop Breeding and Applied Biotechnology 1: 347-354.

Schoonhoven AV and Pastor-Corrales MA (1987) Standard system for the evaluation of bean germoplasma. Centro Internacional de Agricultura Tropical, Cali, 53p.

Scott AJ and Knott MA (1974) Cluster analysis method for grouping means in the analysis of variance. Biometrics 30: 507-512.

Silva FBB, Ramalho MAP, Abreu AFB and Rosa HJA (2011) Multiline as strategy to reduce damage caused by Colletotrichum lindemuthianum in common bean. Journal of Phytopathology 159: 175-180.

Singh SP and Schwartz HF (2010) Breeding common bean for resistance to diseases: A review. Crop Science 159: 2199-2223. 